\title{
The Substrate Constant for Dissolved Molecular Oxygen of Methanol-assimilating Yeasts
}

\author{
By W. J. MIDDELHOVEN, J. BERENDS, \\ A. J. M. VAN AERT AND J. BRUINSMA \\ Laboratory of Microbiology, Landbouwhogeschool, Wageningen, The Netherlands
}

(Received I9 June 1975; revised I4 October 1975)

\section{INTRODUCTION}

The pathway of methanol metabolism by some yeast species has been elucidated recently. It is initiated by an inducible alcohol oxidase, a flavoprotein producing formaldehyde and hydrogen peroxide from methanol and oxygen (Tani et al., I972; Fujii \& Tonomura, 1972; Sahm \& Wagner, 1973). Catalase is induced together with alcohol oxidase (Roggenkamp, Sahm \& Wagner, 1974). Both enzymes may be contained within peroxisome-like microbodies, which are present in large amounts during growth on methanol, but not during growth on ethanol or glucose (van Dijken et al., I975).

Most aerobic micro-organisms have respiration rates which are constant over a wide range of oxygen concentrations. Diminished respiration rates are only observed at concentrations below approximately $0.2 \mathrm{mg} \mathrm{O} / \mathrm{l}$. Apparently, the substrate constant for dissolved oxygen is of this order of magnitude. Preliminary chemostat experiments with methanol-assimilating yeasts suggested that in yeast cultures with methanol as the sole source of carbon and energy, higher oxygen concentrations might be needed to avoid oxygen limitation of the growth rate than in cultures with other carbon sources.

In the present investigation the substrate constant for molecular oxygen, defined as the oxygen concentration $\left(\mathrm{mg} \mathrm{O}_{2} / \mathrm{l}\right)$ at which the respiration rate is half the maximum, is determined for resting yeast cells grown on and respiring with methanol or ethanol as the sole source of carbon and energy.

\section{METHODS}

Strains. The yeast strains studied were kindly supplied by the Centraal Bureau voor Schimmelcultures, Yeast Division, Delft, The Netherlands, unless stated otherwise. Strains used were Candida boidinii Ramirez CBS2428 and strain B isolated from soil; Hansenula capsulata Wickerham CBSI993; Hansenula philodendra van der Walt \& Scott CBS6075, Kloeckera sp. strain 220I (isolated and described by Ogata, Nishikawa \& Ohsugi, 1969); Pichia trehalophila Phaff, Miller \& Spencer CBS536r ; Torulopsis nemodendra van der Walt et al. CBs6280.

Growth of cultures. The growth medium consisted of $\left(\mathrm{g}^{-1}\right)$ : methanol or ethanol, 2; ammonium chloride, 0.38 ; sodium sulphate, $\mathrm{O} \cdot \mathrm{I}$; trace elements and vitamins according to Middelhoven (I969); potassium phosphate buffer, o.I M, pH 6.0. With $H$. capsulata, H. philodendra and $T$. nemodendra, yeast extract ( $5 \mathrm{~g} / \mathrm{l}$ methanol medium) was added to increase the growth rate. The yeast strains were precultivated at $30{ }^{\circ} \mathrm{C}$ in conical flasks. Young cultures $(\mathrm{r} \mathrm{ml})$ were inoculated into $\mathrm{I} 00 \mathrm{ml}$ medium in a $300 \mathrm{ml}$ conical flask. Incubation took place at $30{ }^{\circ} \mathrm{C}$ in a rotary shaker (Gallenkamp) at $200 \mathrm{rev} . / \mathrm{min}$. The growth period varied with the 


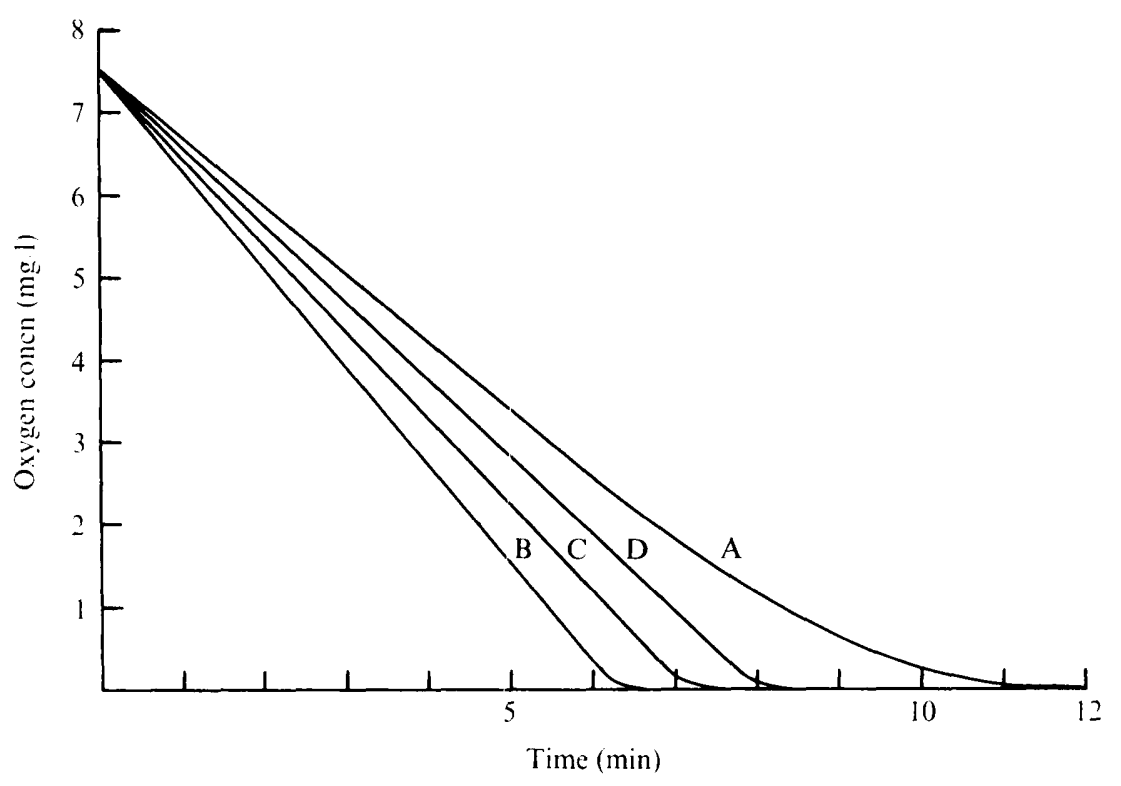

Fig. I. The oxygen uptake by resting Candida boidinii strain B cells grown with methanol or ethanol as the sole source of carbon and energy. The oxygen uptake by resting cells respiring endogenously or with growth substrate was recorded. $\mathrm{A}$ and $\mathrm{B}$, methanol-grown cells; $\mathrm{C}$ and $\mathrm{D}$, ethanol-grown cells. Cell densities and other conditions were $\left(\mathrm{g} \mathrm{I}^{-1}\right)$ : A, yeast $0 \cdot 19$, methanol $\mathrm{I} \cdot 0$; $\mathrm{B}$, yeast $3 \cdot 8$, respiring endogenously; $C$, yeast 0.6 , ethanol $\mathrm{I} \cdot 0 ; \mathrm{D}$, yeast 3.5 , respiring endogenously.

strain and the carbon source. All cells were harvested in the exponential growth phase when no more than $50 \%$ of the maximum cell yield had been attained, as indicated by extinction measurements. The cultures were chilled and centrifuged. The yeast cells were washed three times with ice-cold $0 . \mathrm{I}$ M-potassium phosphate buffer $\mathrm{pH} 6.0$ and used within $2 \mathrm{~h}$ for respirometer experiments. Cell density was determined as the dry weight of the culture, or by comparison of the $E_{623}$ with a standard curve.

Oxygen uptake. The rate of oxygen uptake was determined with Biological Oxygen Monitor model 530 I (Yellow Springs Instruments Co. Inc.) coupled to a $100 \mathrm{mV}$ potentiometer. The rates of both endogenous and exogenous substrate respiration were measured in $5 \mathrm{ml}$ air-saturated $0 \cdot 1$ M-potassium phosphate buffer $\mathrm{pH} 6 \cdot 0$. The substrate concentration was I $\mathrm{g} \mathrm{l}^{-1}$, which was sufficient to consume $95 \%$ of the oxygen in 5 to $\mathrm{I} 5 \mathrm{~min}$ at $30^{\circ} \mathrm{C}$.

\section{RESULTS AND DISCUSSION}

Oxygen uptake by ethanol-grown cells, respiring either with ethanol substrate or endogenously, is independent of $\mathrm{O}_{2}$ concentration down to the limit of sensitivity of the instrument (about $0.15 \mathrm{mg} / \mathrm{l} \mathrm{O}_{2}$ ) or less (Fig. I, curves C and D; only data for C. boidinii strain B are shown since other strains behaved similarly). Thus, as with other organisms, the substrate zonstant for $\mathrm{O}_{2}$ was very low. This was also observed with methanol-grown yeasts respiring sndogenously (curve B), except in the case of $H$. capsulata.

With methanol as substrate, the oxygen uptake became dependent upon the residual $\mathrm{O}_{2}$ :oncentration at a much higher concentration (Fig. I, curve A). This could not have been lue to the accumulation of inhibitory dissimilation products such as formaldehyde, as oxyzen uptake continued after the yeast suspension had been re-saturated with air. Reciprocal 
Table I. The substrate constants for oxygen of methanol-assimilating yeast strains grown in methanol medium

Resting yeast cells grown in methanol medium were suspended in buffer. The oxygen uptake of cells respiring endogenously or with methanol was measured and recorded. The calculation of the substrate constant is described in Results and Discussion.

\begin{tabular}{l}
\multicolumn{1}{c}{ Yeast species } \\
Candida boidinii \\
Hansenula capsulata \\
Hansenula philodendra \\
Kloeckera sp. \\
Pichia trehalophila \\
Torulopsis nemodendra
\end{tabular}

Strain number
CBS2428
Strain B
CBS1993
CBS6075
220 I
CBS536I
CBS6280

\begin{tabular}{|c|c|}
\hline \multicolumn{2}{|c|}{$K_{\mathrm{O}_{2}}\left(\mathrm{mg} \mathrm{l}^{-1}\right)$} \\
\hline $\begin{array}{l}\text { Endogenous } \\
\text { respiration }\end{array}$ & $\begin{array}{l}\text { Respiration } \\
\text { with methanol }\end{array}$ \\
\hline$\approx 0.15$ & $I \cdot O$ \\
\hline$\approx 0.15$ & $I \cdot 3$ \\
\hline$\approx \begin{array}{l}0.7 \\
\approx 0.15\end{array}$ & $\begin{array}{l}0.6 \\
0.8\end{array}$ \\
\hline$\approx 0.15$ & 0.8 \\
\hline$\approx 0.15$ & 0.5 \\
\hline$\approx 0.15$ & 0.7 \\
\hline
\end{tabular}

plots of the rate of $\mathrm{O}_{2}$ consumption versus $\mathrm{O}_{2}$ concentration are linear. Values for the substrate constant $K_{\mathrm{O}_{2}}$ ' calculated from the regression lines are listed in Table I. Substrate constants for oxygen of the various yeast strains were high for cells respiring with methanol, and very low for cells (except $H$. capsulata) respiring endogenously.

It appears that methanol-assimilating yeast species show at least two types of respiration: one endogenously or with ethanol as the substrate, and one with methanol as the substrate. Oxygen uptake due to the former type proceeded at a constant rate at $\mathrm{O}_{2}$ concentrations down to about $0.15 \mathrm{mg} \mathrm{l}^{-1}$. Respiration with methanol as the substrate showed substrate constants for oxygen between 0.5 and $\mathrm{I} \cdot 3 \mathrm{mg} \mathrm{O} / \mathrm{l}$. Possibly these high values are due to the involvement of alcohol oxidase (a flavoprotein) in the primary reaction between oxygen and methanol. Nevertheless, we found that respiration on methanol is inhibited by 50 to $80 \%$ by $0.2 \mathrm{~mm}$-potassium cyanide, a potent inhibitor of cytochrome oxidase-mediated respiration. This suggests that terminal respiration in methanol-assimilating cells is partly mediated by cytochrome oxidase and partly by the system responsible for the high substrate constant for $\mathrm{O}_{2}$. Attempts to inhibit respiration on methanol with salicyl hydroxamate, an inhibitor of the cyanide-resistant respiration of Candida lipolytica (Henry, Hamaide-Deplus \& Nyns, I974) and Neurospora crassa (Edwards, Rosenberg \& Maroney, 1974), were unsuccessful as the compound was non-toxic to the strains studied at concentrations $<5 \mathrm{gl}^{\mathbf{- 1}}$.

We thank Dr C. J. E. A. Bulder for critical reading of the manuscript and Miss Marry Reinink for technical assistance.

\section{REFERENCES}

van Dijken, J. P., Veenhuis, M., Kreger-van RiJ, N. J. W. \& Harder, W. (I975). Microbodies in methanolassimilating yeasts. Archives of Microbiology ro2, $4 \mathrm{I}-44$.

Edwards, D. L., RosenberG, E. \& Maroney, P. A. (1974). Induction of cyanide-insensitive respiration in Neurospora crassa. Journal of Biological Chemistry 249, 355 I-3556.

Fuji, T. \& Tonomura, K. (1972). Oxidation of methanol, formaldehyde and formate by a Candida species. Agricultural and Biological Chemistry 36, 2297-2306.

henry, M. F., Hamaide-Deplus, M. C. \& Nyns, E. J. (1974). Cyanide-insensitive respiration of Candida lipolytica. Antonie van Leeuwenhoek 40, 79-9I.

Middelhoven, W. J. (1969). Enzyme repression in the arginine pathway of Saccharomyces cerevisiae. Antonie van Leeuwenhoek 35, 215-226. 
Ogata, K., Nishikawa, H. \& Ohsugi, M. (1969). Yeast capable of utilizing methanol. Agricultural and Biological Chemistry 33, I5I9-I 520.

Roggenkamp, R., SAHM, H. \& Wagner, F. (1974). Microbial assimilation of methanol. Induction and function of catalase in Candida boidinii. FEBS Letters 41, 283-286.

SAHM, H. \& WAGNER, F. (1973). Microbial assimilation of methanol. The ethanol- and methanol-oxidizing enzymes of the yeast Candida boidinii. European Journal of Biochemistry 36, 250-256.

TANi, Y., Miya, T., NishikaWA, H. \& OGata, K. (1972). The microbial assimilation of methanol. I. Formation and crystallisation of methanol-oxidizing enzyme in a methanol-utilizing yeast, Kloeckera sp. No. 220I. Agricultural and Biological Chemistry 36, 68-75. 